WARSZTATY Z GEOGRAFII TURYZMU

ISBN 978-83-7969-138-8 $\quad$ s. 121-135

http://dx.doi.org/10.18778/7969-138-8.09

Ewa Jolanta STROIK

Uniwersytet im. Adama Mickiewicza w Poznaniu

\title{
KOMERCJALIZACJA USEUG TURYSTYCZNYCH NA PRZYKŁADZIE RYNKU NIEMIECKIEGO
}

\section{Wstęp}

Komercjalizacja w szerokim ekonomicznym znaczeniu jest dostosowaniem przedsiębiorstw do gospodarki rynkowej, w węższym rozumiana jest powszechnie jako handel, czyli np. sprzedaż produktów. Jej przejawy można zaobserwować w prawie każdym działaniu handlowym, marketingowym, $\mathrm{w}$ procesach tworzenia obejmujących fazę od pomysłu do kształtowania usług czy towarów stanowiących nowe produkty turystyczne lub ich pakiety. Działania ukierunkowane na komercjalizację rynku turystycznego wymagają analizy relacji zachodzących pomiędzy podstawowymi elementami tego rynku, tj. popytem i podażą turystyczną.

Niemcy jako państwo plasują się na wysokich pozycjach w rankingach turystycznych zarówno w odniesieniu do turystyki wyjazdowej, jak i przyjazdowej. Tradycje w odbywaniu licznych podróży są głęboko zakorzenione w społeczeństwie niemieckim, co znajduje odzwierciedlenie np. w bogactwie terminów opisujących rodzaje podróży. Rynek usług turystycznych, silnie skomercjalizowany, rozwija się prężnie za sprawą popytu na wyjazdy urlopowe, długo- i krótkoterminowe. $Z$ drugiej strony komercjalizacji usług turystycznych sprzyja rozwinięty rynek touroperatorów i licznych biur podróży, a także rozbudowana infrastruktura turystyczna. Działania i aktywności wspierające rozwój turystyki podejmowane są nie tylko na płaszczyźnie 
krajowej, ale też lokalnej. Regiony turystyczne Niemiec, poszczególne gminy podejmują inicjatywy mające na celu stymulowanie turystyki przyjazdowej, natomiast działania marketingowe promujące Niemcy jako miejsce warte odwiedzenia docierają do rozmaitych zakątków świata.

Celem pracy jest przedstawienie wybranych działań związanych z komercjalizacją niemieckiego rynku turystycznego. Działania te będą ukazane na tle roli Niemiec w turystyce światowej zarówno wyjazdowej, jak i przyjazdowej, a także w odniesieniu do obecnych trendów. Dalszym etapem rozważań będzie rozpoznanie trendów od strony popytu, poprzez analizę cech i motywów odbiorców usług turystycznych, a także od strony podaży, głównie na podstawie wybranych produktów $\mathrm{z}$ oferty wiodących touroperatorów na rynku niemieckim. Komercjalizacja przejawia się także we współpracy na poziomie regionów turystycznych. Z uwagi na wąskie ramy niniejszego opracowania przytoczone zostaną jedynie wybrane przykłady dobrych praktyk mających na celu podniesienie atrakcyjności regionu.

\section{Od produktu turystycznego do komercjalizacji}

Punktem wyjścia rozważań jest definicja produktu turystycznego autorstwa J. KACZMARKA, A. STASIAKA i B. WŁODARCZYKA (2010, s. 82), zgodnie z którą „produkt turystyczny to zintegrowany układ oczekiwań, korzyści i wrażeń tworzących unikatową (niepowtarzalną) kompozycję trzech podróży: wyobrażonej, rzeczywistej i zapamiętanej". Takie rozumienie stawia przed ofertą turystyczną nie lada wyzwanie, ale też i szanse. Chociaż w dalszych częściach artykułu dominują zestawienia statystyczne służące porównaniom, to jednak wszelkim zjawiskom i aspektom turystyki towarzyszą wartości niematerialne, subiektywne: oczekiwania, przeżycia, doświadczenia, które stanowią jej istotę i siłę napędową. Ową istotę podróżowania w szerszym kontekście dostrzega D. MACCANNEL (2002, s. 36): „Wartości takich rzeczy, jak nowoczesne programy, wycieczki, kursy, reportaże, artykuły, pokazy, konferencje, pochody, opinie, wydarzenia, widoki, spektakle, sceny i sytuacje, nie określa ilość pracy włożonej w ich wykonanie. Ich wartość jest pochodną jakości i siły doświadczenia, które obiecują". W takim ujęciu znacznie trudniej jest sprostać oczekiwaniom potencjalnych turystów i z sukcesem zachęcić ich do przyjazdu, nawet używając sprawdzonych narzędzi komercjalizacji. 
Zgodnie z definicją „komercjalizacja” oznacza „oparcie czegoś na zasadach handlowych, rozwijanie handlu; nastawienie na handel, na zysk" (TOKARSKI, red. 1971, s. 370; też Kopaliński). Spotyka się także definicje wywodzące "komercjalizację" z angielskiego commerce oznaczającego handel lub wymianę handlową (KALINOWSKI, URYSZEK 2009). W myśl powyższych definicji, działania komercyjne zawierają się w pojęciu "rynek”, obejmującym wzajemne interakcje między popytem i podażą, „istniejącym tam, gdzie popyt spotyka się z podażą" (CHUDOBA 2008, s. 15). Przy czym komercjalizacja przejawia się na rynku turystycznym na różne sposoby. We wspomnianym już szerokim rozumieniu ekonomicznym oznacza dostosowanie przedsiębiorstw do warunków gospodarki rynkowej. Przejawy komercjalizacji obserwujemy we wszelkich działaniach związanych ze sprzedażą usług i produktów turystycznych. Obejmuje ona działania: od oferowania przez touroperatorów imprez turystycznych i prześciganiu się $\mathrm{w}$ wartościach dodanych w celu uatrakcyjnienia oferty, poprzez wynajem prywatnych domków letniskowych $\mathrm{w}$ ciekawych turystycznie regionach, aż do różnego rodzaju dosprzedaż $\mathrm{y}^{1} \mathrm{w}$ formie pamiątek lub gotowego nagrania obejrzanego właśnie spektaklu itp. „Turysta dzięki temu, że się przemieszcza, dzięki oznaczeniom miejsc, produkcji pamiątek i całych scenerii aranżowanych dla jego przyjemności może uczestniczyć w wytwarzaniu kultury" (MACCANNELL 2002, s. 21), ale też generuje przejawy działań komercyjnych. Gdzie leżą przyczyny postępującej komercjalizacji? Jakie procesy można zauważyć w ostatnich latach? Przede wszystkim rynek turystyczny jest prężny i mocno rozwinięty. Sprzyja temu pozytywny klimat konsumpcyjny, w destynacjach turystycznych PKB wzrasta, dynamicznie rozwijają się handel zagraniczny i inwestycje, maleje bezrobocie, wzrasta produkcja oraz sprzedaż (Analizy rynków... 2011, 2012, 2013). Sytuacja gospodarcza i na rynku pracy w Niemczach jest stabilna, co pozytywnie wpływa na rozwój rynku turystycznego.

\section{Przejawy komercjalizacji widoczne w nazewnictwie turystycznym}

"Granice mojego języka są granicami mojego świata" (L. Wittgenstein) - tym cytatem można rozpocząć podrozdział o bogatych tradycjach Niemców w podróżowaniu i rozwoju turystyki, które znajdują odzwierciedlenie

${ }^{1}$ Sprzedaż dodatkowej oferty, zazwyczaj o wartości do 30\% sprzedanego towaru, usługi. 
w warstwie językowej, np. w wielości terminów opisujących podróże. Przyjrzyjmy się wybranym przykładom wyrazów utworzonych tylko z członem "-reise". Duża liczba i bogactwo przytoczonych terminów jest nieformalnym dowodem potwierdzającym skalę komercjalizacji rynku turystycznego w Niemczech. Większość z przytoczonych terminów stanowi bowiem elementy oferty turystycznej i jest powszechnie stosowana, zrozumiała, a także czytelna dla przeciętnego obywatela.

Tabela 1. Bogactwo terminologii opisującej rodzaje wyjazdów turystycznych

\begin{tabular}{|c|l|l|}
\hline Lp. & \multicolumn{1}{|c|}{ Termin niemiecki } & \multicolumn{1}{|c|}{ Tłumaczenie na język polski } \\
\hline 1 & die Ausstellungsreise & wyjazd na wystawę \\
\hline 2 & die Bausteinreise & podróż modułowa \\
\hline 3 & die Bildungsreise & podróż edukacyjna/naukowa \\
\hline 4 & die Entdeckungsreise & podróż odkrywcza \\
\hline 5 & die Eventreise & wyjazd na ciekawe wydarzenie \\
\hline 6 & die Fernreise & podróż do dalekich destynacji, np. na Karaiby \\
\hline 7 & die Festspielreise & wyjazd na festiwal \\
\hline 8 & die Forschungsreise & podróż badawcza \\
\hline 9 & die Gastspielreise & występy gościnne \\
\hline 10 & die Hochzeitsreise & podróż poślubna \\
\hline 11 & die Konzertreise & wycieczka na koncert \\
\hline 12 & die Langzeitreise & podróż długoterminowa \\
\hline 13 & die Last-Minute-Reise & wycieczka last minute \\
\hline 14 & die Literaturreise & podróż tropami literatury, podróż literacka \\
\hline 15 & die Musicalreise & wycieczka na musical \\
\hline 16 & die Nostalgiereise & podróż sentymentalna \\
\hline 17 & die Opernreise & wycieczka do opery \\
\hline 18 & die Pilgerreise & pielgrzymka; peregrynacja \\
\hline 19 & die Rundreise & wycieczka objazdowa \\
\hline 20 & die Seereise & rejs \\
\hline 21 & die Städtereise & wycieczka do miasta \\
\hline 22 & die Studienreise & pobyt edukacyjny \\
\hline 23 & die Tagesreise & podróż jednodniowa \\
\hline 24 & die Theaterreise & wyjazd połączony z wyjściem do teatru \\
\hline 25 & die Volunteer-Reise & wyjazd w ramach wolontariatu \\
\hline 26 & die Weiterreise & dalsza podróż \\
\hline 27 & die Weltreise & podróż dookoła świata \\
\hline 28 & die Zeitreise & podróż w czasie \\
\hline & & \\
\hline
\end{tabular}

Źródło: opracowanie własne na podstawie różnych źródeł.

Uderzająca $\mathrm{w}$ powyższych przykładach precyzja w definiowaniu typów podróży, czytelność terminologii należy notabene do specyfiki języka nie- 
mieckiego. Ale mnogość pojęć i ich powszechne stosowanie ukazują, jak głęboko zakorzenione są tradycje podróżnicze. Świadczą one także o różnorodności oferty turystycznej, uważnym dostosowaniu jej do zróżnicowanych segmentów rynku turystycznego, co potwierdzają też dane statystyczne.

\section{Turystyka wyjazdowa Niemców}

Obywatele Niemiec przodują w skali światowej w wydatkach ponoszonych na wyjazdy turystyczne i tym samym mają znaczne udziały w ekonomicznym rozwoju tak turystyki, jak i gospodarki odwiedzanych krajów. W roku 2012 Niemcy wydali łącznie na turystykę 83,8 mld \$ i tym samym uplasowali się na drugiej pozycji w skali światowej. Liderem w 2012 r. po raz pierwszy zostały Chiny (102 mld \$), natomiast tuż za Niemcami znalazły się Stany Zjednoczone (83,5 mld \$) (Tourism... 2013)². Z uwagi na fakt, że Niemcy byli w latach wcześniejszych "mistrzami świata w podróżowaniu” (Analizy rynków... 2011, 2012) w rankingu, w którym oprócz wydatków ponoszonych na turystykę brano pod uwagę też liczbę wyjazdów zagranicznych, warto przyjrzeć się bliżej niemieckiej kulturze podróżowania. Termin „kultura podróżowania" wydaje się uzasadniony ze względu na wieloletnie tradycje Niemców w odbywaniu podróży urlopowych, biznesowych i innych. Z socjologicznego punktu widzenia definicję kultury trafnie ujmuje D. MAC CANNEL (2002, s. 40): „Każda kultura to szereg modeli życia. Modele te podlegają organizacji na wiele sposobów według wszelkich znanych zasad logiki, także kilku takich, które są nam jak dotychczas nieznane: podobieństwa, opozycji, przeciwieństwa, komplementarności, równoległości, analogii". W jaki sposób modele dominujące w społeczeństwie niemieckim wpisują się w globalne trendy? W roku 2012 „Niemcy odbyli łącznie 69,3 mln podróży urlopowych trwających co najmniej pięć dni" (Analiza rynkówv... 2012, s. 114). Wśród nich 53,6 mln podróży stanowiło główny wyjazd urlopowy, natomiast $15,7 \mathrm{mln}$ wyjazdy drugie i kolejne (Analiza rynkóww... 2013). Biorąc pod uwagę fakt, że liczba mieszkańców Republiki Federalnej Niemiec wynosi prawie $82 \mathrm{mln}$ trzeba stwierdzić, że jest to wynik imponujący. Z danych FUR (Forschungsinstitut Urlaub und Reisen e.V. 2013) wynika, iż w okresie od listopada 2011 r. do grudnia 2012 r. niemieckojęzyczni mieszkańcy Nie-

2 Dla porównania łączna wartość światowych wydatków poniesionych na turystykę w roku 2012 wyniosła 1075 mld \$ (Tourism... 2013). 
miec w wieku od 14 do 70 lat odbyli łącznie 79,6 mln podróży krótkookresowych, trwających 24 dni (wzrost w stosunku do 2011 o 1,8\%). Analizie poddano od jednej do trzech podróży krótkookresowych o łącznym wolumenie $74,5 \mathrm{mln}$. Z tej liczby $76 \%(56,3 \mathrm{mln})$ wyjazdów stanowiły podróże krajowe, natomiast $24 \%(18,2 \mathrm{mln})$ wyjazdy zagraniczne. Ulubionym celem wyjazdów krajowych (Forschungsgemeinschaft... 2013) była Bawaria $(10,7 \mathrm{mln}$, wliczając wyjazdy do miast). Na pozycji drugiej uplasowała się Nadrenia Północna-Westfalia $(5,6 \mathrm{mln})$. Wśród wyjazdów krajowych znaczną liczbę, bo aż 43\% (24 mln) stanowiły łącznie wyjazdy do miast. W tej kategorii wyjazdów zdecydowanie największą popularnością cieszyła się stolica - Berlin, w dalszej kolejności Hamburg i Monachium. Warto wspomnieć, że nawet takie miasta, jak Drezno czy Kolonia były częściej odwiedzane niż Londyn znajdujący się na szczycie listy najczęściej odwiedzanych miast-destynacji podczas wyjazdów zagranicznych Niemców. Spośród krótkookresowych wyjazdów zagranicznych Niemcy odbyli łącznie 6,2 mln podróży do miast. Najbardziej popularne kierunki wyjazdów to Austria $(3,2 \mathrm{mln})$, Niderlandy (2,2 mln), dalej Francja $(1,6 \mathrm{mln})$, Hiszpania $(1,6 \mathrm{mln})$, Wielka Brytania $(1,5 \mathrm{mln})$, Szwajcaria $(1,5 \mathrm{mln})$, Włochy $(1,5 \mathrm{mln})$, Czechy $(1,1 \mathrm{mln})$, Polska $(0,6 \mathrm{mln})$ i Dania $(0,5 \mathrm{mln})$ (Forschungsgemeinschaft... 2013).

Mimo że prawie $1 / 3$ wyjazdów Niemców stanowią podróże krajowe, to chętnie wyjeżdżają oni także poza granice swojego kraju. Dominują podróże zagraniczne do Hiszpanii, Włoch, Turcji, Austrii, Chorwacji, Francji, Polski, Grecji, Egiptu i Holandii, a także podróże dalekie. Z podróży trwających minimum pięć dni aż 69\% stanowiły wyjazdy zagraniczne, a liczba wyjazdów krajowych była znacząca i wynosiła 31\% (Analizy rynków... 2011, 2013).

\section{Turystyka przyjazdowa do Republiki Federalnej Niemiec}

Niemcy pozostawały długo liderem w światowej turystyce wyjazdowej, ale także $w$ turystyce przyjazdowej znajdują się na znaczących pozycjach w pierwszej dziesiątce państw w ujęciu globalnym. Turystyka jako znacząca gałąź gospodarki zapewnia i tworzy miejsca pracy, pozwala na przeprowadzanie kolejnych inwestycji. Turystyce przypisuje się wartość dodaną brutto w wysokości 214,1 mld euro, co odpowiada 9,7\% całej gospodarki niemieckiej (Forschungsgemeinschaft... 2013). 
W roku 2012 w skali światowej zanotowano około 1,035 mld przyjazdów turystów (Tourism..., o 3,8\% więcej niż w 2011 r.). Największą popularnością cieszył się stary kontynent, odnotowano 534,8 mln zagranicznych przyjazdów turystycznych. Wśród ulubionych światowych destynacji Niemcy uplasowały się w roku 2012 na pozycji 7. (za Francją, Stanami Zjednoczonymi, Chinami, Hiszpanią, Włochami i Turcją) z liczbą 30,4 mln odwiedzin turystów zagranicznych, ale też pod względem przychodów osiąganych z turystyki zajęły miejsce 7., z kwotą 38,1 mld \$ (Tourism... 2013). W roku 2012 odnotowano 68 827,7 tys. noclegów gości zagranicznych w Niemczech, co wskazuje na wzrost o 8,1\% w stosunku do roku 2011. Do Niemiec najchętniej przyjeżdżają Holendrzy, a także Szwajcarzy, Amerykanie i Brytyjczycy. Zasadniczo Europejczycy generują $3 / 4$ przyjazdów do Niemiec (Jahresbericht 2012, s. 25-26). Wśród destynacji turystycznych najchętniej wybieranych przez Europejczyków Niemcy już po raz trzeci z rzędu zajmują drugie miejsce, za Hiszpanią, natomiast przed Francją. Obywatele nacji europejskich odbyli 45,8 mln podróży turystycznych do Niemiec, spośród których 53\% stanowiły wyjazdy urlopowe, w połowie krótkoterminowe i w połowie długoterminowe (Jahresbericht 2012, s. 25-26).

Warto podkreślić, że Niemcy zajmują czołową pozycję jako kraj docelowy podróży biznesowych innych nacji europejskich z liczbą 12,5 mln przyjazdów w roku 2012, przed Francją i Wielką Brytanią (odpowiednio 4,6 i 4,5 mln) (Jahresbericht 2012, s. 52). Sprawozdanie Ministerstwa Gospodarki i Technologii Niemiec podaje nawet kwotę bliską $13 \mathrm{mln}$ przyjazdów (wzrost w stosunku do roku 2011 o 12,3\%) i plasuje Niemcy na pierwszym miejscu jako organizatora międzynarodowych imprez targowych oraz jako kraj obrad i kongresów (Tourismuspolitischer... 2012, s. 8), także dlatego, że Hanower, Kolonia i Frankfurt stanowią trzy z pięciu największych na świecie terenów targowych, a $2 / 3$ najważniejszych branżowych imprez targowych $\mathrm{w}$ skali świata odbywa się na terenie Niemiec (Jahresbericht 2012, s. 52). Reasumując można stwierdzić, że $27 \%$ wszystkich europejskich podróży do Niemiec stanowią przyjazdy biznesowe. Rozwojowi koniunktury sprzyjają korzystne ceny w stosunku do oferowanych usług, wysokiej klasy hotele konferencyjne i centra kongresowe, a także pozytywny wizerunek (Tourismuspolitischer... 2013, s. 8). W segmencie podróży kulturowych Niemcy znalazły się na pozycji lidera, przed Francją i Włochami (Jahresbericht 2012, s. 27). Powyżej przytoczone dane statystyczne ukazują pozycję Niemców na międzynarodowym rynku turystycznym zarówno ze względu na generowany popyt na wyjazdy turystyczne, jak i podaż w zakresie oferty turystycznej. Oprócz da- 
nych ilościowych opisujących rynek turystyczny do istotnych należą także zmienne jakościowe, pozwalające na głębszą analizę działań związanych z komercjalizacją.

\section{Analiza popytu rynku turystycznego Niemiec}

Pojęcie „turysta" pierwotnie - zgodnie z etymologią słowa - oznaczało „osobę podróżującą lub odwiedzającą dane miejsce w czasie urlopu/wakacji, często w grupie; osobę podróżującą dla przyjemności, np. za granicę" (ZAJADACZ 2008, s. 167). Współcześnie określenie „Turysta [...] ma dwa znaczenia. Oznacza prawdziwych turystów: pochłoniętych zwiedzaniem, przeważnie członków klasy średniej, rozproszonych w tej chwili po całym świecie w poszukiwaniu doznań. [...] Turysta jest realnie istniejącym człowiekiem, czy też turystami są w rzeczywistości ludzie z krwi i kości. Równocześnie «turysta» jest jednym z najlepszych modeli opisujących ogólnie człowieka nowoczesnego. Wydaje mi się, że to właśnie $\mathrm{w}$ umyśle turysty rodzi się pierwsze pojmowanie cywilizacji nowoczesnej" (MACCANNELL 2002, s. 1). Społeczeństwo niemieckie lubi podróżować. Głównymi motywami podjęcia podróży są: słońce, ciepły klimat, chęć korzystania z pięknej pogody, relaks i beztroska, uwolnienie od sytuacji stresujących i presji, nabranie dystansu do dnia codziennego oraz nabranie sił, pozytywnej energii (Forschungsgemeinschaft... 2013). Wyjazdy urlopowe planowane są z dużym wyprzedzeniem, a kupowane często zaraz po ukazaniu się katalogu $\mathrm{z}$ nową ofertą. Klienci niemieccy są bardzo lojalni, zadowoleni ze świadczonych usług, chętnie korzystają $\mathrm{z}$ nich ponownie. Często też udają się na wypoczynek $\mathrm{w}$ to samo miejsce, do tego samego hotelu, jeśli spełnił on ich wysokie wymagania. Cenią komfort, wysoki standard i bezpieczeństwo.

Wśród środków lokomocji Niemcy najczęściej wybierają samochód (50\%) i samolot $(30 \%)$, rzadziej natomiast autokar $(8 \%)$ i kolej $(8 \%)$ (Jahresbericht 2012, s. 33; dane POT 2012 to: samochód 47\%, samolot 37\%, autokar 8\% i kolej 5\%). W kwestii zakwaterowania, największym powodzeniem cieszą się hotele (46\%), domki letniskowe (24\%) i kempingi (7\%) (Analizy rynków... 2013).

Jakie tendencje są dostrzegalne współcześnie w zakresie popytu? Rośnie liczba klientów indywidualnych, natomiast główny wyjazd urlopowy ulega skróceniu na rzecz kolejnych wyjazdów w tym samym roku. Z jednej strony 
obserwujemy wzrost kosztów ponoszonych na wyjazd urlopowy, bowiem turyści niemieccy wydali w roku 2012 większe kwoty na osobę na jedną podróż urlopową - średnio 914 euro (w 2011 - 868 euro, natomiast w 2010 861 euro). Z drugiej strony wzrasta zainteresowanie noclegiem w domkach letniskowych i na kempingach; ceny urlopu odgrywają znaczącą rolę. Nieznacznie zmniejsza się liczba noclegów w hotelach, na rzecz domków letniskowych i kempingów (Analiza rynków... 2011, 2012, 2013).

Popularnością cieszą się podróże autokarowe. W latach 2010-12 podróż autokarową odbyło $12 \%$ społeczeństwa, natomiast $20 \%$ jest zainteresowana podróżą autokarową w przyszłości. W roku 2012 odbyto „,5,8 mln podróży autokarowych, trwających ponad 5 dni i około 15 mln podróży krótkich, trwających od dwóch do czterech dni" (Analiza rynków... 2012, s. 117). Zauważalny jest ogromny potencjał w odbywaniu podróży do miast. Trend ten wykazuje tendencję wzrostową. Aktualnie około $40 \%$ obywateli Niemiec rozważa odbycie podróży do miasta w ciągu najbliższych trzech lat (RA).

Najwyraźniej rysująca się tendencja wskazuje na drastyczne zmniejszenie liczby turystów korzystających z podróży organizowanych przez biura podróży z 45\% w roku 2010 do 34\% w roku 2012 i zwiększenie liczby podróży organizowanych samodzielnie z 55\% (2010) do 66\% (2012). Obserwujemy mniejsze zainteresowanie ofertami biur podróży, głównym źródłem informacji jest Internet, który wypiera ogniwo pośrednictwa. Klienci chętniej korzystają z innych kanałów dystrybucji, tj. portale społecznościowe czy listy mailingowe. W roku 2012 59\% europejskich turystów zakupiło swoją podróż zagraniczną za pośrednictwem Internetu, co wskazuje na wzrost znaczenia tego sposobu o ponad $10 \% \mathrm{w}$ stosunku do roku 2011. Łącznie $74 \%$ ankietowanych używało Internetu przy przygotowaniu lub rezerwacji podróży (Jahresbericht 2012, s. 76, za IPK).

\section{Podaż na rynku turystycznym Niemiec}

Analiza przykładów i przejawów komercjalizacji w zakresie podaży będzie dotyczyła dwóch kluczowych zagadnień. Pierwsze to ukazanie współczesnych trendów na przykładzie działalności rynkowej trzech największych niemieckich touroperatorów, do których należą: TUI Deutschland, Touristik der REWE Group oraz Thomas Cook, przedsiębiorstwa liczące się w skali globalnej (tab. 2), ponieważ w ich działalności można zauważyć nowe przejawy 
komercjalizacji, o których będzie mowa w dalszej części rozważań. W kolejnym podrozdziale zostaną omówione wybrane przykłady dobrych praktyk z komercyjnej działalności na płaszczyźnie regionalnej, która leży u podstaw kształtowania i warunkowania turystyki przyjazdowej do Niemiec.

Działalność komercyjna trzech największych touroperatorów w Niemczech znajduje odzwierciedlenie w wysokości obrotów $\mathrm{w}$ ostatnich latach, a także w procentowym udziale w obrotach rynku turystycznego. Wartości te przedstawia tab. 2. Zauważalny jest trend obniżania procentowego udziału w obrotach, natomiast wartość obrotów z roku na rok rośnie.

Tabela 2. Obroty i udział w rynku trzech największych touroperatorów

\begin{tabular}{|l|c|c|c|c|c|c|}
\hline \multirow{2}{*}{ Touroperator } & \multicolumn{2}{|c|}{$2010 \mathrm{r}$. } & \multicolumn{2}{|c|}{2011 r. } & \multicolumn{2}{|c|}{2012 r. } \\
\cline { 2 - 7 } & $\begin{array}{c}\text { obroty } \\
\text { (mln } \\
\text { euro) }\end{array}$ & $\begin{array}{c}\text { udział } \\
\text { w obrotach } \\
\text { rynku w } \%\end{array}$ & $\begin{array}{c}\text { obroty } \\
(\mathrm{mln} \\
\text { euro })\end{array}$ & $\begin{array}{c}\text { udział } \\
\text { w obrotach } \\
\text { rynku w } \%\end{array}$ & $\begin{array}{c}\text { obroty } \\
\text { (mln } \\
\text { euro) }\end{array}$ & $\begin{array}{c}\text { udział } \\
\text { w obrotach } \\
\text { rynku w \% }\end{array}$ \\
\hline $\begin{array}{l}\text { TUI } \\
\text { Deutschland }\end{array}$ & 3843,5 & 23,10 & 4212,5 & 18,1 & 4471,6 & 18,3 \\
\hline $\begin{array}{l}\text { Touristik der } \\
\text { REWE Group }\end{array}$ & 2977,6 & 17,89 & 3099,6 & 13,3 & 3175,7 & 13,1 \\
\hline Th. Cook & 2850,0 & 17,13 & 3000,0 & 12,9 & 3200,0 & 13,1 \\
\hline
\end{tabular}

Źródło: Analizy rynków... (2010, 2011, 2012).

Odnotowano sukcesywny wzrost obrotów u większości touroperatorów, ale też większą liczbę uczestników wyjazdów, maleje natomiast drastycznie liczba biur podróży. „Według Zrzeszenia Niemieckich Biur Podróży DRV w 2012 roku zmniejszyła się liczba biur podróży w Niemczech do 9986. W 2011 roku istniało prawie 10240 biur, a w 2010 aż 10 370" (Analiza rynkótw... 2013, s. 116). Komercjalizacja usług zmierza w kierunku oferowania internetowej bazy noclegów, wyjazdów. Touroperatorzy używają nowych kanałów dystrybucji, zakładają i prowadzą strony internetowe na serwisach społecznościowych, tj. Facebook, Twitter, traktując je jako skuteczne źródło zamieszczenia i przybliżania oferty, a także pozyskania potencjalnych klientów. Klienci znajdą w Internecie wszelkie informacje, wybiorą podróż marzeń, zapoznają się z opiniami innych turystów, a także dokonają płatności. Ponad połowa Niemców korzystała z Internetu jako źródła informacji przy planowaniu urlopu (Analiza rynkótv... 2013).

Dostrzegalnym działaniem jest też profilowanie oferty touroperatorów, którzy chcą sprostać specyficznym oczekiwaniom klientów, usiłując wypeł- 
nić swoją ofertą nisze rynkowe oraz stwarzając produkty mające zaspokoić specyficzne potrzeby indywidualnych nabywców (o niszy rynkowej A. KANIEWSKA-SĘBA 2007). W ofercie touroperatorów, obok klasycznych, standardowych wyjazdów, pojawiają się oferty dla gości o indywidualnych preferencjach, np. ceniących wysoki standard obsługi, kontakt z przyrodą i regionalną kuchnię, wypoczynek na plaży (w tej ofercie pojawiają się najczęściej hotele z własną plażą, wyposażoną w leżaki i parasole), ofertę wellness, życie nocne $\mathrm{i}$ in.

Touroperatorzy zabiegają o każdego klienta. Trwają prace nad ujednoliceniem piktogramów informujących o dostępności obiektów hotelowych. Dane o dostępności zawarte są także w opisach hoteli; szczegółowych informacji udziela centrum rezerwacji telefonicznej touroperatora. Klienci mają możliwość zabrania kota lub psa na wakacje do wybranych obiektów, nawet na wakacje lotnicze. W miarę możliwości spełniane są tzw. niezobowiązujące życzenia klienta (prośba o udostępnienie łóżeczka dla dziecka, pokoju z widokiem na morze lub w spokojnym położeniu, zakwaterowanie zaprzyjaźnionych rodzin blisko siebie itp.). Klienci niemieccy często z tych życzeń korzystają. Innym przykładem komercjalizacji, wpływającej na rozszerzenie wartości dodanej produktu, jest oferta parku rozrywki Hansa Park w Sierksdorf. Mama z dzieckiem, która zapomni o zabraniu rzeczy z samochodu, może zwrócić się o pomoc do pracowników parku, którzy daną rzecz przyniosą jej z pobliskiego parkingu. Pracownicy parku pilnują także np. miejsca w kolejce do atrakcji. Dzięki tak oferowanej pomocy grono osób korzystających z oferty parku powiększa się.

Częstą praktyką touroperatorów są upusty cenowe dla określonych grup wiekowych, np. dla dzieci lub seniorów, a także oferta typu „singiel z dzieckiem", kiedy to za dziecko w pokoju dwuosobowym, przy minimalnym dwuosobowym obłożeniu, płaci się obniżoną cenę. Touroperatorzy, chcąc się pozytywnie wyróżnić, poza ofertą podstawową oferują także np. wliczony $\mathrm{w}$ cenę pakietu turystycznego przejazd pociągiem z miejsca zamieszkania do miasta wylotu, odprawę online lub gwarantują najniższą cenę albo zwrot pieniędzy przy uzasadnionym niezadowoleniu z oferty. Dużą wagę przywiązują też do monitorowania bezpieczeństwa $w$ rejonach docelowych i szkolą pracowników na wypadek zaistnienia niebezpieczeństwa, np. ataków terrorystycznych. 


\section{Komercjalizacja regionów turystycznych Niemiec}

Promocją Niemiec jako destynacji turystycznej zajmuje się „Deutsche Zentrale für Tourismus e.V., które reprezentuje Niemcy na zlecenie Ministerstwa Gospodarki i Technologii Niemiec i jest przez nie wspierana na mocy uchwały Bundestagu. Do jej zadań należy tworzenie wizerunku i rozwój produktów i strategii, tak samo, jak i dystrybucja, badanie rynku, reklama i promocja" (Jahresbericht 2012, s. 16). DZT corocznie opracowuje cele strategiczne i je raportuje. Ale też na płaszczyźnie regionalnej podejmowane są działania komercyjne aktywizujące rozwój turystyki.

Przykładowo, miejscowości kraju związkowego Szlezwik-Holsztyn, położone nad Morzem Bałtyckim, w zamian za pobierane opłaty klimatyczne oferują gościom „Ostseecard”, uprawniającą do zniżek w licznych obiektach rozrywkowych i gastronomicznych regionu. Stanowi to jednocześnie doskonałą reklamę obiektów, zachęca do uiszczania opłaty także gości domków letniskowych, natomiast gminom pozwoliło z pozyskanych środków na stworzenie i utrzymanie doskonałej infrastruktury nadmorskiej, promenady, tras rowerowych, placów zabaw.

Innym przykładem jest rejon południowej Bawarii Ostallgäu, gdzie turystom nocującym $\mathrm{w}$ obiektach noclegowych rejonu umożliwiono darmowe korzystanie $\mathrm{z}$ komunikacji publicznej. To krok zachęty do odwiedzenia atrakcji regionu, ułatwienie $\mathrm{w}$ dotarciu do celów i działanie sprzyjające ochronie środowiska, poprzez zmniejszenie ruchu komunikacyjnego.

Reasumując, komercjalizacja przejawia się na płaszczyźnie regionalnej w sposób różnorodny, jednak zawsze głównym celem jest osiągnięcie jak największych korzyści ekonomicznych przy maksymalnym zadowoleniu klienta, który powinien korzystać nie tylko $\mathrm{z}$ oferty stricte turystycznej przedsiębiorstw, ale też z szeroko rozumianego produktu turystycznego obsZaru (NIEZGODA, ZMYŚLONY 2003).

\section{Wnioski}

Komercjalizacja niemieckiego rynku turystycznego jest tematem istotnym, nie tylko ze względu na wiodącą rolę Niemiec w turystyce światowej, w wyznaczaniu trendów, które silnie oddziałują i przenikają na rynki turystyczne innych państw, głównie europejskich, ale także ze względu na rozbudowane 
i skuteczne działania marketingowe przyciągające do Niemiec rzesze turystów. Niemcy wyznaczają trendy w turystyce współczesnej zarówno w zakresie popytu, jak i charakteru podaży, co jest widoczne także w kreowaniu pojęć językowych.

Współczesna komercjalizacja dostrzegalna na niemieckim rynku turystycznym ma wiele "twarzy” i dynamicznie reaguje na współczesne trendy. Z jednej strony zauważamy dużą różnorodność segmentów rynku turystycznego (dostosowanie oferty do indywidualnych oczekiwań klientów), z drugiej prężną aktywność promocyjną Niemiec na arenie krajowej i regionalnej. $\mathrm{Na}$ znaczeniu zyskuje turystyka organizowana indywidualnie, następuje "skracanie" drogi pośrednictwa i rezygnacja z usług biur podróży, natomiast wzrasta rola Internetu $\mathrm{w}$ dystrybucji ofert i informacji, co przyczynia się do spadku liczby biur podróży. Krócej trwa główny wyjazd urlopowy, zastąpiony tendencją do odbywania kilku krótszych urlopów w roku. Klientów niemieckich cechuje także duża lojalność wobec dostawców usług turystycznych, związana $\mathrm{z}$ wysokim stopniem satysfakcji. Wyniki analiz związane z działaniami komercyjnymi na niemieckim rynku turystycznym zwracają uwagę na coraz większą indywidualizację potrzeb współczesnych turystów, generującą konieczność różnicowania oferty w zakresie podaży. Kluczowe znaczenie $w$ tym procesie ma poczucie satysfakcji z wyjazdu. W odniesieniu do powyższych obserwacji dominujących trendów do najważniejszych współczesnych przejawów komercjalizacji niemieckiego rynku turystycznego można zaliczyć:

1) aktywne pakietowanie - łączenie ofert, usług i poszczególnych produktów w jeden produkt o zryczałtowanej cenie;

2) „wzbogacanie” produktów - rozbudowanie warstw produktu poszerzonego, oczekiwanego i psychologicznego o dodatkowe elementy (KACZMAREK, STASIAK, WŁODARCZYK 2010);

3) nowatorstwo w kreowaniu i indywidualizację ofert, jako próbę wypełnienia nisz rynkowych, np. stworzenie kategorii podróży modułowej, w przypadku której klient realizuje własną koncepcję podróży, tworząc ją z wybranych modułów;

4) spowodowanie, że elementy o potencjalnej zdolności do przynoszenia zysku stają się przedmiotem handlu, wprowadzanie nowych elementów usług czy produktów na rynek (KALINOWSKI, URYSZEK 2009);

5) działania marketingowe wykraczające poza przedsiębiorstwa turystyczne, łączenie ofert wielu przedsiębiorstw na płaszczyźnie regionów, wspólna dynamiczna promocja; 
6) nowe sposoby dystrybucji informacji i ofert za pośrednictwem mediów elektronicznych (wykorzystanie portali internetowych i mediów społecznościowych);

7) podniesienie poziomu świadczonych usług, nie tylko $w$ fazie informacji o produkcie (szeroki dostęp do szczegółowych informacji o dostępności obiektów, także dla osób niepełnosprawnych), ale także $\mathrm{w}$ fazie świadczenia usług (pomoc matkom z dziećmi);

8) waga i staranność przykładane do badania satysfakcji z odbytych podróży, a także implementacja tych wyników.

Trzeba zaznaczyć, że wymienione przejawy komercjalizacji wzajemnie się na siebie nakładają, zazębiają i uzupełniają. W przypadku niemieckiego rynku turystycznego tworzą gęstą sieć wzajemnych powiązań, przynosząc wymierne korzyści turystom preferującym wysokiej jakości usługi, zaś przedsiębiorstwom - wymierne korzyści ekonomiczne. Badania związane z rozpoznaniem stopnia satysfakcji, czynników wpływających na komfort i dyskomfort podróżowania wydają się podstawowym źródłem danych, które pozwalają w sposób optymalny kształtować zmiany na rynku turystycznym nie tylko niemieckim, ale każdym, który dąży do osiągnięcia sukcesu w warunkach narastającej konkurencji.

\section{BIBLIOGRAFIA}

Analiza rynków zagranicznych. Trendy, komercjalizacja - na podstawie raportów przedstawicieli POT za rok 2012, maj 2013, Warszawa.

Analizy rynków zagranicznych 2010 na bazie sprawozdań Polskich Ośrodków Informacji Turystycznej + Chiny i Indie, 2011, Warszawa.

Analizy rynków zagranicznych 2011 na bazie sprawozdań Polskich Ośrodków Informacji Turystycznej, Polska Organizacja Turystyczna, maj 2012.

CHudoba T., 2008, Marketing w turystyce, CeDeWu, Warszawa.

Forschungsgemeinschaft Urlaub und Reisen, 2013, Newsletter Kiel.

Jahresbericht 2012, Deutsche Zentrale für Tourismus e.V.

KACZMAREK J., STASIAK A., WŁODARCZYK B., 2010, Produkt turystyczny. Pomyst, organizacja, zarzadzanie, PWE, Warszawa.

KALINOWSKI B., URYSZEK T., 2009, Zasady komercjalizacji i finansowania innowacyjnych rozwiązań, [w:] Komercjalizacja wyników badań naukowych - krok po kroku", Kraków; www.unidruk. com.pl.

KANiEWSKA-SĘBA A., 2007, Segmentacja rynku, [w:] B. Pilarczyk, H. Mruk (red.), Kompendium wiedzy o marketingu, Wyd. Naukowe PWN, Warszawa.

MacCANnell D., 2002, Turysta. Nowa teoria klasy próżniaczej, WWL Muza SA, Warszawa. 
NieZgoda A., ZmYŚLOnY P., 2003, Popyt turystyczny. Uwarunkowania i perspektywy rozwoju, Wyd. Akademii Ekonomicznej, Poznań.

TOKARSKI J. (red.), 1971, Stownik wyrazów obcych, Państwowe Wydawnictwo Naukowe, Warszawa.

Tourism Highlights, 2013, UNWTO.

Tourismuspolitischer Bericht der Bundesregierung 17. Legislaturperiode, Bundesministerium für Wirtschaft und Tourismus, 2013.

ZAJADACZ A., 2008, Ruch turystyczny jako przedmiot badań geograficznych, [w:] Z. Młynarczyk,

A. Zajadacz (red.), Uwarunkowania i plany rozwoju turystyki, t. II: Zasoby antropogeniczne. Krajobraz. Ruch turystyczny, ser. „Turystyka i Rekreacja - Studia i Prace” 2, Wyd. Naukowe UAM, Poznań, s. 187-209.

www.allgeau-mobil.de.

www.bmwi.de.

www.fur.de.

www.germany.travel. www.ostseecard.de. www.rewe-group.de. www.thomascook.de. www.tui.de.

www.welt.de. 